\title{
ABNORMAL LIPID METABOLISM IN OBSTRUCTIVE JAUNDICE DUE TO MULTIFOCAL \\ BILIARY TRACT CARCINOMAS
}

\author{
G. G. MUIR, M.B., M.Sc.*
}

R. E. Cotton, M.D. $†$

From the Bland Sutton Institute of Pathology and Courtaıld Institute of Biochemistry, Middlesex Hospital, London

SEVERE, rapidly progressive, obstructive jaundice is probably most frequently due to neoplastic obstruction of the biliary tract either within the hepatic substance or in its extra-hepatic part. The obstruction when complete produces profound metabolic changes which are on the whole poorly understood and these changes are reflected in changes in the blood chemistry. In the differential diagnosis of a patient with jaundice the laboratory tests are of great assistance and a better understanding of the abnormalities of metabolism produced should lead to more accurate laboratory diagnosis.

This case report is of interest because of the very severe abnormalities of lipid metabolism produced by obstruction of the biliary tract by coexistent multiple carcinomas of the gall bladder and intra- and extra-hepatic portions of the biliary system. Detailed studies of the lipid abnormalities have been carried out in the hope that they might throw some light on the basic changes which occur.

\section{Case History}

The patient was a female of 55 years with a history of three weeks painless jaundice following a course of chlorpropamide. Over the past ten years she had been treated for mild diabetes mellitus by dietary methods with little success. Six weeks previously she had been admitted for reassessment and stabilization with chlorpropamide. Apart from her underlying diabetes with complications of retinopathy and mild peripheral

* Present address: St. Bartholomew's Hospital, London, E.C.r.

† Present address: City Hospital, Nottingham. neuritis, she appeared in good health. The clinic@ chemistry performed at that time (June 2) was essentialf) normal although the transaminase levels were at the upper limit of normal (table I). After stabilization of her diabetes she was discharged on chlorpropamide, $600 \mathrm{mg}$. per day, with a diet of 800 calories and 80 gramis carbohydrate, but ten days later she developed jaundice of progressive intensity which necessitated readmissiom

On Admission. She was found to have gross hepat 3 megaly and severe jaundice. The clinical chemistix (August 25) showed an overall picture of intrahepate obstruction. Ten days later these findings were cont firmed, abnormalities being greater. Chlorpropamide was changed to soluble insulin in the light of the hepatoxicity of chlorpropamide and her worsening diabetes. Her insulin requirements increased throughts out the course of her illness.

At this time the serum was observed to be opalescent after refrigeration. In view of the history of chlorpro pamide administration it was, at first, decided to obserw her progress, but by the 22nd laparotomy was deemee essential. The clinical chemistry on that day (Septemben 15) is shown in table 1 .

Operation. At laparotomy she was shown to multiple tumour nodules in the liver which proved to be adenocarcinomatous on frozen section examinat

There was a small amount of ascitic fluid which was analysed and found to be compatible with a malignan effusion with the appropriate changes of the lactin dehydrogenase and the transaminases.

Progress. She became anuric on the third pos? operative day. Clinical chemistry on the eighth pos operative day showed the changes indicated in the table of a rapidly deteriorating liver function and bloof urea of $165 \mathrm{mg} . / 100 \mathrm{ml}$. The patient died on the $12 \mathrm{fH}$ post-operative day, eight weeks from the onset of jaundice.

Biochemical Investigations were carried out on the sera taken shortly before operation to try and elucidate

Table 1.-Liver Function Tests

\begin{tabular}{|c|c|c|c|c|c|c|c|c|c|c|c|c|c|c|}
\hline Date & $\begin{array}{c}\text { Bili- } \\
\text { rubin } \\
\text { mgms. } \\
\text { per } \\
\text { roo ml. }\end{array}$ & $\begin{array}{c}\text { Van } \\
\text { den } \\
\text { Bergh } \\
\text { Direct } \\
\text { Re- } \\
\text { action }\end{array}$ & $\begin{array}{l}\text { Alka- } \\
\text { line } \\
\text { Phos- } \\
\text { phatase } \\
\text { K-A } \\
\text { Units }\end{array}$ & $\begin{array}{c}\text { Thy- } \\
\text { mol } \\
\text { Turbid- } \\
\text { ity } \\
\text { Units }\end{array}$ & $\begin{array}{c}\text { Zinc } \\
\text { Sulph- } \\
\text { ate } \\
\text { Turbid- } \\
\text { ity } \\
\text { Units }\end{array}$ & $\begin{array}{l}\text { Pro- } \\
\text { throm- } \\
\text { bin } \\
\text { Con- } \\
\text { centra- } \\
\text { tion }\end{array}$ & $\begin{array}{l}\text { Total } \\
\text { Pro- } \\
\text { tein } \\
\text { g./roo } \\
\text { ml. }\end{array}$ & $\begin{array}{c}\text { Albu- } \\
\text { min } \\
\text { g./roo } \\
\text { ml. }\end{array}$ & $\begin{array}{l}\text { Globu- } \\
\text { lin } \\
\text { g./100 } \\
\text { ml. }\end{array}$ & $\begin{array}{l}\text { Hæmo- } \\
\text { globin } \\
\text { g./roo } \\
\text { ml. }\end{array}$ & $\begin{array}{c}\text { Fæcal } \\
\text { Fat } \\
\text { g./24 } \\
\text { hrs. }\end{array}$ & $\begin{array}{c}\text { Choles- } \\
\text { terol } \\
\text { mg./ I0o } \\
\text { ml. }\end{array}$ & $\begin{array}{c}\text { Serum } \\
\text { glu- } \\
\text { tamic } \\
\text { Oxalo- } \\
\text { acetic } \\
\text { Trans- } \\
\text { amin- } \\
\text { ase } \\
\text { Units } \\
\text { roo ml. }\end{array}$ & $\begin{array}{c}\text { Serue } \\
\text { glu- } \\
\text { tamie } \\
\text { Pyru } \\
\text { vate } \\
\text { Trans } \\
\text { amin } \\
\text { ase } \\
\text { Unit. } \\
\text { roo mi. }\end{array}$ \\
\hline $\begin{array}{l}\text { June } 2 \\
\text { Day } 0\end{array}$ & $\begin{array}{c}\text { Less } \\
\text { than } \\
0.4\end{array}$ & $\begin{array}{c}\text { Nega- } \\
\text { tive }\end{array}$ & 12 & Normal & Normal & $100 \%$ & 6.8 & 3.9 & 2.9 & 11.9 & - & 一 & 50 & \\
\hline $\begin{array}{l}\text { Aug. } 25 \\
\text { Day } 1\end{array}$ & 14.2 & $\begin{array}{c}\text { Posi- } \\
\text { tive }\end{array}$ & 70 & 4 & I 5 & 一 & 6.3 & 2.9 & 3.4 & 10.5 & 14.4 & 800 & 35 & \\
\hline $\begin{array}{l}\text { Sept. } 4 \\
\text { Day II }\end{array}$ & 14.4 & $\begin{array}{c}\text { Posi- } \\
\text { tive }\end{array}$ & 84 & 6 & 5 & - & 6.3 & 2.4 & 3.9 & 一 & - & 1540 & IOI & \\
\hline $\begin{array}{l}\text { Sept. } 15 \\
\text { Day } 22\end{array}$ & 17.5 & $\begin{array}{c}\text { Posi- } \\
\text { tive }\end{array}$ & 95 & 3 & 5 & 79 & 5.6 & 2.6 & 3.0 & 9.8 & 12.8 & 1810 & 250 & \\
\hline $\begin{array}{l}\text { Sept. } 20 \\
\text { Day } 27\end{array}$ & 25 & $\begin{array}{c}\text { Posi- } \\
\text { tive }\end{array}$ & 71 & 4 & 5 & 79 & - & - & - & 一 & - & 1960 & 90 & \\
\hline
\end{tabular}


TABLE 2

Ultracentrifuge ANALYSIS

\begin{tabular}{|c|c|c|c|}
\hline & $\begin{array}{l}\text { Lipoprotein } \\
\text { mg./100 mls. } \\
\text { Patient's sera }\end{array}$ & $\begin{array}{l}\text { Nor- } \\
\text { mal } \\
\text { sera }\end{array}$ & $\begin{array}{c}\text { Patient's sera } \\
\text { after } \\
\text { refrigeration }\end{array}$ \\
\hline $\begin{array}{lr}\text { Sf } & 0-12 \\
\text { Sf } & 12-20 \\
\text { Sf } & 20-100 \\
\text { Sf } & 100-400\end{array}$ & $\begin{array}{r}580 \\
484 \\
2,503 \\
290\end{array}$ & $\begin{array}{r}339 \\
51 \\
106 \\
75\end{array}$ & $\begin{array}{r}508 \\
133 \\
193 \\
0\end{array}$ \\
\hline
\end{tabular}

TABLE 3

Cholesterol mg./100 ml.

Total 1729

$20 \%$ esterified

Lipoprotein cholesterol

Sf $0-12$

Sf $12-400$

High density lipoprotein 230

the serum lipid pattern. Ultracentrifugation was performed using Goffman's methods and the results are shown in table II; there were marked increases in all fractions of lipoproteins. Table II also shows the results of ultracentrifugation before and after refrigeration, the major changes being in the Sf 12 to 400 fractions.

Table III shows a more detailed analysis of the distribution of the serum chlesterol.

Thin layer and paper chromatography were carried out using the following methods.

Extraction of serum lipids (Mcllivain and Rodnight, 1962).

$0.5 \mathrm{ml}$. of serum was homogenized with $9.5 \mathrm{ml}$. of chloroform-methanol $(2: 1 \mathrm{v} / \mathrm{v})$ and filtered through sintered glass. The filter was washed with the solvent mixture. The filtrate and washes were taken to dryness at a temperature not exceeding $60^{\circ} \mathrm{C}$. $1.0 \mathrm{ml}$. of chloroform-methanol $(2:$ I $\mathrm{v} / \mathrm{v})$ containing $4 \%(\mathrm{v} / \mathrm{v})$ of water was added to the flask. This procedure was repeated twice after taking to dryness. The final residue was extracted several times with small volumes of chloroform-methanol, filtered free of insoluble matter, the filter being washed with the same solvent mixture. The filtrate was made up to $0.5 \mathrm{ml}$. with chloroform-methanol.

Thin layer chromatography was performed with Kieselgel G (Merck) silicic acid according to the method of Wagner, Horhammer and Wolff (I96I). The chromatograms were sprayed with the phospate, ninhydrin and choline spray reagents.

Paper chromatography of the lipids in the serum sample without prior extraction was carried out on silicic-acid impregnated paper according to the method of Marinetti and Stotz (1960), $20 \mathrm{ml}$. of the pathological and normal sera being applied as adjacent spots.

Chromatography showed an increase in cholesterol, cholesterol esters, free fatty acids and neutral fats. The phospholipid distribution showed a marked difference from normal sera; lecithin was much reduced while sphingomyelin and phosphatidyl ethanolamine were slightly increased. On thin layer chromatography, spots were found with $R_{\mathrm{Fs}}$ similar to those of glycocholic and taurocholic aic.

Post mortem appearances. The body was that of an obese, heavily jaundiced female. Death was due to broncho-pneumonia associated with bilateral lower lobe collapse of the lungs caused by bronchial obstruction by muco-purulent secretions.

There was a healing laparotomy wound and the peritoneal cavity was largely obliterated by adhesions, mostly fibrinous and particularly marked around the liver.

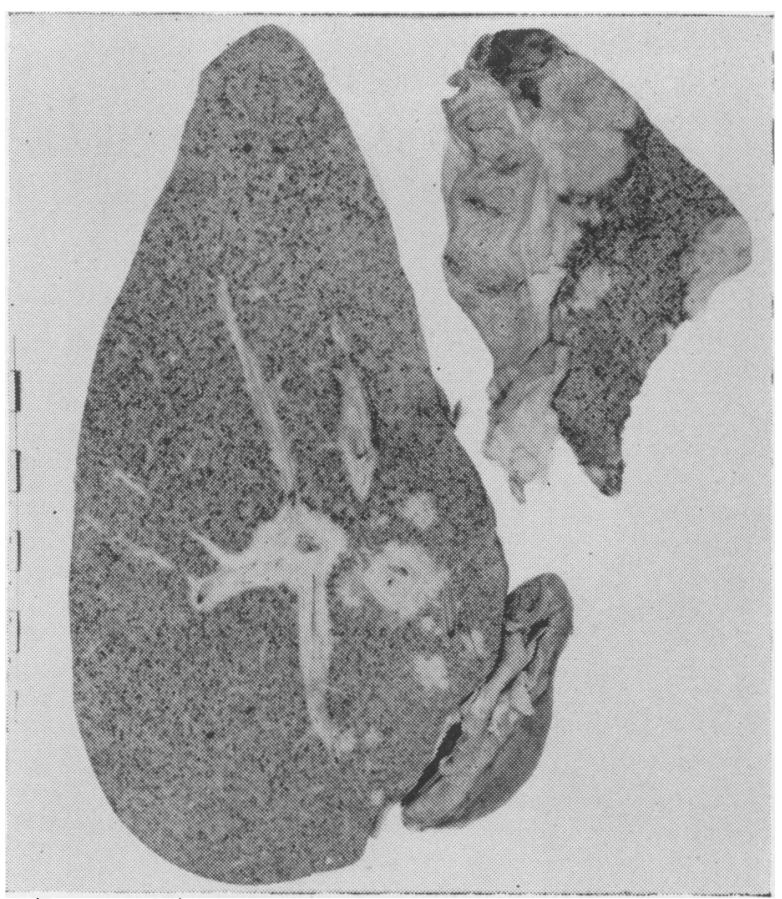

FIG. I. - The larger slice of mottled, bile-stained liver was taken near the hilum and shows sclerotic, pale, tumour tissue ensheathing the major bile ducts and portal vessels. The smaller slice shows irregularity of the gall bladder mucosa with ulceration and extension of tumour into the hepatic substance.

$$
\times 0.4
$$

The liver was grossly and diffusely enlarged (weight $90 \mathrm{oz}$.) and it was an intense, rather uniform, dark-green colour. The gall bladder was slightly shrunken ( $3 \frac{1}{2}$ ins. long and maximum internal diameter of $\frac{3}{4}$ in.) there were no stones and the lumen contained pale and very mucoid bile at apparently normal tension. There was generalized thickening of the wall, most marked posteriorly near the fundus where there was mucosal irregularity, nodularity and central ulceration $I$ in. diameter. This was hard and gritty on section with replacement of the entire wall by white tumour which extended into the hepatic substance as a mass of maximum diameter 2 in. The impression from the gross appearances was of a primary carcinoma of the gall bladder directly invading the liver. There were numerous smaller tumour nodules in all areas of the hepatic substance, the largest $\frac{3}{4}$ in. diameter. At the hilum of the liver, the common hepatic duct was completely obstructed by similar hard white tumour and the larger intra-hepatic bile ducts of both right and left lobes, together with their accompanying portal vein branches, were ensheathed over considerable lengths by very scirrhous tumour radiating from the hilum (Fig. I). The portal vein at the hilum was incompletely obstructed by thrombus and tumour within the lumen, but in its extra-hepatic course it appeared normal. The spleen was of normal size (weight $8 \mathrm{oz}$.) and showed no gross abnormality. The extra-hepatic bile ducts were collapsed but showed no obvious abnormality of their walls and calculi were not found in any part of the biliary tract. Pressure on the gall bladder produced a ready flow of contents into the duodenum. Enlarged, hard, tumourinvaded lymph nodes, largest 3 in. diameter, were 


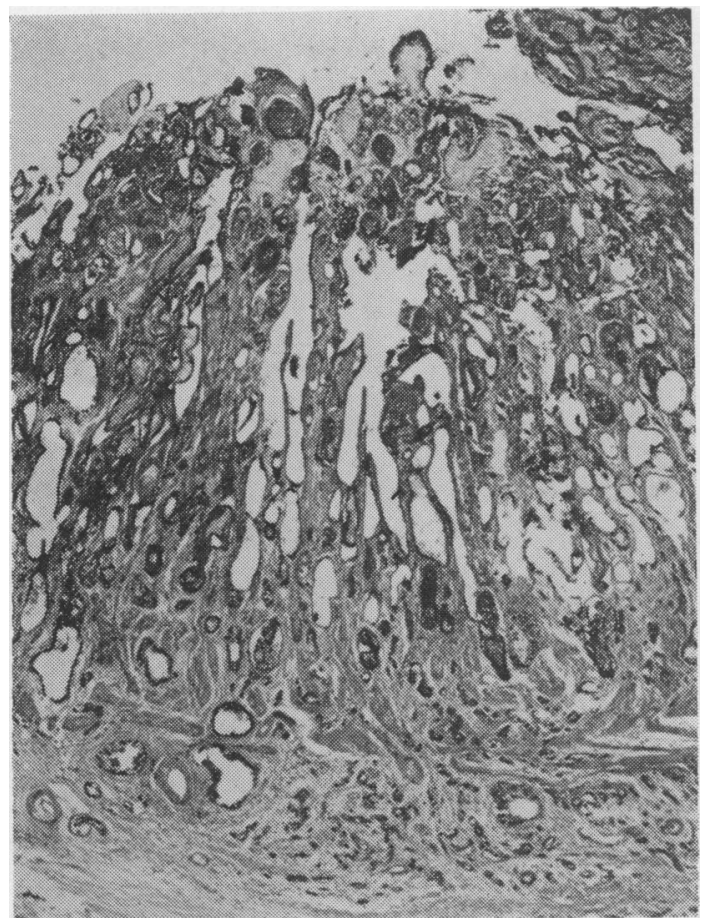

FIG. 2.-Section of the gall bladder wall showing mucus-secreting adenocarcinoma replacing the mucosa and invading through all layers.

Hæmatoxylin and eosin $\times 25$

found in the hepatic hilum, along the upper border of a normal pancreas and in the root of the mesentery. Other groups of nodes appeared normal and tumour was not found in any other organ.

The liver parenchyma showed on section diffuse mottling due to bile pigmentation and bile exuded from small ducts on the cut surface. There was no gross evidence of fibrosis nor of infarction and the lobular pattern was exaggerated by the biliary obstruction.

The kidneys were markedly bile-stained and swollen (weight $13 \mathrm{oz}$. and $14 \mathrm{oz}$.) and on section showed swelling of the cortex with pallor, loss of pattern and some loss of cortico-medullary differentiation. The appearances suggested acute renal tubular necrosis and this was confirmed by histological examination.

Microscopical Findings. The gall bladder showed widespread severe chronic cholecystitis with thickening of the wall and formation of Rokitansky-Aschoff sinuses. In the region of the tumour, a transition could be traced from chronic cholecystitis to atypical epithelial proliferation and finally invasive mucus-secreting adenocarcinoma with invasion of all coats of the wall and direct extension into the liver (Fig. 2). Several blood vessels in the gall-bladder bed were filled with tumour.

The obstructed common hepatic duct and the ensheathed large intra-hepatic bile ducts and portal vein branches showed similar tumour, mostly in periductal fibrous tissue and within the lumen of portal vein branches and distended lymphatics. Many of the large bile ducts, however, also showed areas of highly atypical epithelium with, in places, papillary projections into the lumen. In other sites, foci of invasive carcinoma were present, apparently arising from the epithelium of

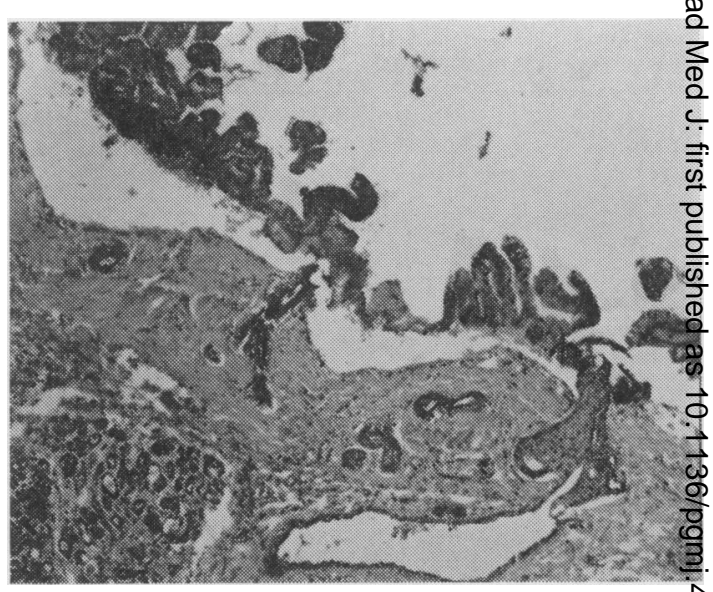

FIG. 3.-Pancreatic duct with artefactual detachment $\stackrel{\overrightarrow{\sigma f}}{\text { of }}$ atypical, hyperplastic, papillary lining epithelium anff metaplastic change of the epithelium at the origen of a branch.

Hæmatoxylin and eosin $\times$

ducts of variable size. Intervening areas of the ductaํ. mucosa appeared normal.

Liver tissue removed at laparotomy and at autopsy showed similar histological changes. There was prese vation of lobular structure, intense bile-staining of liver cells and distended intra-lobular bile canalicutr. Liver cells at the periphery of the lobules shopreg degenerative changes and some cell necrosis and there was slight replacement fibrosis. No evidence of infarction was seen. although many portal vein radsicles contained tumour. The portal tracts showed a modera焦 lymphocytic infiltrate and increase in fibrous tissue and the smaller bile ducts were, in most areas, hyperplast or somewhat distended. The appearances were thes those of severe obstructive jaundice with early biliag cirrhosis.

Although the extra-hepatic biliary tract and t $\overrightarrow{\vec{m}}$ pancreas appeared macroscopically normal, the ept thelium lining the common bile duct showed multipte areas of atypical proliferative activity with papillacy projections into the lumen. The pancreatic duct and its tributaries showed similar changes (Fig. 3) with are of focal frank malignancy.

\section{Discussion}

훌.

Two main topics of interest are apparent frogn this case. Firstly, the metabolic changes, partic larly in respect of the lipids, are extremely sevege and rapidly progressive, and the detailed invest gation of these changes throw some light on the possible mechanism of production. Secondly the is the finding of widespread carcinoma arising multifocally in the biliary tract.

The very gross rise in the serum cholester 0 during the last three weeks of her illness, although a common feature of intra-hepatic obstructive jaundice, is not usually so acute, except in jaundige due to certain drugs (Read, Harrison and Sherlock, I96I). The alteration observed in the ratio of free to esterified cholesterol is common in hepatocellular jaundice. The lipid abnormalities are, howeves, difficult to explain precisely. In biliary cirrhosfs ultra-centrifugation of serum lipoproteins shows more commonly a decrease in the high-densigy 
lipoprotein cholesterol (Lindgren and Nichols I 960), but in this case it appears that this fraction is greatly increased. The low-density lipoprotein pattern is similar in distribution to that in biliary cirrhosis, but the magnitude of the changes more closely resembles that of the uncontrolled ketotic diabetic. Also it is unusual for biliary cirrhosis or obstructive jaundice to show a high neutral fat or, as this case does, a high free fatty acids level (Ahrens and Kunkel 1949). It is of interest that mice with rapidly growing malignant tumours, provided that their diet is maintained, have a marked hyperlipæmia (Greenstein, 1954).

The changes in the lipid pattern caused by refrigeration are greater than those caused by freezing a normal plasma. It has been shown by Mills and Wilkinson (1962) that little change occurs on refrigeration in normal sera, but in pathological sera with high serum lipid values such changes are more marked. Somewhat similar changes have been recorded in primary biliary cirrhosis by Hurworth and Dangerfield (1962). In their cases they demonstrated a cryolipoprotein which remained at the interface when mixed with saline; in the case recorded above the serum was stabilized by the addition of water. They also showed that in diabetic lipæmia the lipids pass to the saline surface.

It would appear then that the serum lipid changes are best considered as a mixture of those of chronic obstructive jaundice and diabetes millitus. They may well have been accentuated by the presence of a carcinoma of the biliary tree, the marked vascular invasion of the portal system, causing rapid spread throughout the liver parenchyma, might well be the cause of the dramatic onset and rapidity of the lipid changes.

The remaining clinical chemistry is such as would be found in malignant disease with hepatic invasion. In retrospect, the early rise in the transaminases prior to that of the alkaline phosphatase in a case of hepatic invasion is of interest. The presence of normal flocculation tests in the later stages with gross abnormalities of the plasma proteins might well be explained by the presence of a protective globulin found in some hyperglobulinæmias (Naganna, Rao, Venkaiali, and Rao 1962).

The co-existence of carcinomas of the gall bladder and biliary tract is not rare when the sites are carefully examined at autopsy (Willis, 1960), and it seems almost certain that this represents widespread multicentric carcinogenesis rather than a spread via the natural passage of the biliary system (Willis, I 942). In the present case the occurrence of 'skip' areas of normal epithelium between the multiple foci of atypical proliferation, non-invasive carcinoma and invasive carcinoma provide additional evidence in favour of such a view point. Although calculi are commonly held to be carcinogenic in the biliary tract none was found in this case. Alternative chemical carcinogens which might be active in this region are the cholic acid derivatives which are usually present in bile. Such a chemical carcinogenesis would, of course, explain the relative frequency with which these tumours are multifocal, but it must be remembered that carcinomas in this region are rare, probably accounting for only about $3 \%$ of deaths from malignant disease. Some additional and unknown factor thus appears to be necessary for this change.

\section{Summary}

A case of multifocal adenocarcinoma of the biliary tract occurring in a middle-aged female diabetic is presented. There were dramatic changes in the lipid metabolism and the paper describes the attempts made to define these changes and elucidate their cause. The possible explanations are discussed. Detailed analyses of this type in further cases of severe obstructive jaundice might prove to be useful in their differential diagnosis.

We would like to thank Dr. J. D. N. Nabarro for permission to publish this case. We also thank Dr. D. Gammack of the Institute of Psychiatry, Dr. J. R. Wherrart of the Institute of Neurology and Dr. G. L. Mills of the Courtauld Institute for assistance with the lipid analysis.

\section{REFERENCES}

Ahrens, E. M., and Kunkel, H. G. (1949): The Relationship between Serum Lipids and Skin Xanthomata in Eighteen Patients with Biliary Cirrhosis, $\mathcal{F}$. clin. Invest., 28, 1568 .

GreEnStein, J. P. (1954): The Chemistry of the Tumour-Bearing Host in Biochemistry of Cancer, 2nd edition, p. 516. New York and London: Academic Press.

Hurworth, E., and Dangerfield, W. G. (1962) : Unstable Serum Lipoproteins in Biliary Cirrhosis, Clin. chim. Acta., $7,292$.

DE LALlA, O. F., and Gofman, J. W. (1954): Ultracentrifuge Analysis of Serum Lipoproteins in Methods of Biochemical Analysis, vol. I (Ed. D. Glick). New York: Interscience Publishers Inc.

LindGren, F. T., and Nichols, A. V: The Structure and Function of Human Serum Lipoproteins in the Plasma Proteins, vol. II, p. 38 (Ed. F. W. Putnam). New York and London: Academic Press.

MARINETTI, G. V., and STOTZ, E. (1960): Direct chromatography of Serum Lipids without Solvent Extraction, Biochim. biophys. Acta. (Amst.), 37, $57 \mathrm{I}$.

McIlwain, H., and RoDNIGHT, R. (1960): Lipids Extraction, Fractionation and Preparation, Practical Neurochemistry, p. 64. London: J. \& A. Churchill.

Mills, G. L., and Wilkinson, P. A. (1 962): Some Effects of Storage on Plasma Lipoproteins, Clin. Chim. Acta., 7, 685.

Naganna, B., Ramo RaO, B., Venkaiali, K. R., and Lakshmana RaO, P. (1962): Isolation of a Protective Gamma Globulin Fraction interfering with Zinc Sulphate Turbidity, $\mathcal{F}$. Clin. Path., 15, 73.

REAd, A. E., Harrison, C. V., and SHerlock, S. (1961): Chronic Chlorpromazine Jaundice, Amer. F. Med., 31, 249.

WAGNER, H., HorHAMMER, L., and WolfF, H. (196r): Dünnschichtchromatographic von Phosphatiden und Glykolipiden, Biochem. $Z$., 334, 175 .

Willis, R. A. (1960): Epithelial Tumours of the Biliary Tract, Pathology of Tumours, 3rd edition, p. 44r. London: Butterworth.

- (1942): Some Aspects of Pathology of Carcinomata of the Biliary Tract, Med. Y. Aust., ii, 340. 